\title{
Differences in the reproductive endocrine status of ewes in the early post-partum period and during seasonal anoestrus
}

\author{
I. J. Clarke, P. J. Wright*, W. A. Chamley† $\ddagger$ and K. Burman \\ Medical Research Centre, Prince Henry's Hospital, St Kilda Road, Melbourne, Victoria 3004, \\ * Department of Veterinary Clinical Sciences, University of Melbourne, and †Animal Research \\ Institute, Victorian Department of Agriculture, Werribee, Victoria 3030, Australia
}

\begin{abstract}
Summary. More $(P<0.05)$ post-partum acyclic ewes $(8 / 9)$ showed evidence of pulsatile LH release than did seasonally anoestrous ewes $(2 / 8)$. Mean plasma prolactin concentrations were higher $(P<0.05)$ in the post-partum ewes than in the seasonally anoestrous ewes. Hypothalamic and pituitary cytosol oestrogen receptor number, median eminence GnRH content and pituitary LH, FSH and prolactin contents were similar in the two groups of ewes. The number of nuclear-bound oestrogen receptors was greater $(P<0.01)$ in pituitaries from seasonally anoestrous ewes than in pituitaries from post-partum ewes.

These data suggest that the basis of acyclicity in seasonally anoestrous ewes and in post-partum ewes is probably due to their inability to generate $\mathrm{LH}$ pulse frequencies similar to that in the follicular phase of the oestrous cycle. The higher LH pulse frequency in post-partum ewes, compared to that in seasonally anoestrous ewes, suggests that pregnancy may partly negate the reduction in LH secretion that is associated with photoperiod-induced acyclicity. The lower number of nuclear-bound oestrogen receptors in post-partum ewes suggests that there may be lower plasma oestrogen levels and less ovarian follicular growth than in non-suckling anoestrous ewes.
\end{abstract}

\section{Introduction}

Ovarian acyclicity occurs during the post-partum period in sheep that lamb during the mating season despite pulsatile LH release (Wright, Geytenbeek, Clarke \& Findlay, 1981). Pituitary responsiveness to gonadotrophin-releasing hormone (Gn-RH) declines during pregnancy (Chamley, Findlay, Cumming, Buckmaster \& Goding, 1974) and is lower in post-partum ewes lambing during the breeding season than in dioestrous ewes (Wright et al., 1980). Jenkin, Heap \& Symons (1977) and Crowder, Gilles, Tamanini, Moss \& Nett (1982) have reported poor responsiveness to Gn-RH 1 day after parturition but this may return to normal within 11 days (Crowder et al., 1982) to 3 weeks (Jenkin et al., 1977) if ewes do not suckle. Pituitary LH content is restored soon after parturition (Jenkin et al., 1977; Crowder et al., 1982).

Despite these findings, it is apparent that an ovarian or neuroendocrine defect exists in postpartum ewes which prevents the occurrence of regular oestrous cycles. Pituitary Gn-RH receptor levels do not appear to be limiting factors (Crowder, Gilles \& Tamanini, 1981). There is evidence of

‡ Present address: Arthur Rylah Institute, Ministry for Conservation, Heidelberg, Melbourne, Victoria 3084, Australia. 
a defect in the feedback effects of oestrogen that does not allow the normal oestrogen-induced ovulatory LH surges to occur during the early post-partum period in ewes (Wright et al., 1980), monkeys (Yamaji et al., 1971), cows (Radford, Nancarrow \& Mattner, 1978), pigs (Elsaesser \& Parvizi, 1980), and women (Baird, McNeilly, Sawers \& Sharpe, 1979). Also, post-partum ewes appear to be more sensitive to the inhibitory effects of oestrogen than are cyclic ewes (Wright $e t$ al., 1981), which may be analogous to the situation during seasonal anoestrus when the negative feedback effect is greater than during the mating season (Legan, Karsch \& Foster, 1977). Seasonal acyclicity depends upon photoperiod (Karsch, 1980) whereas this is clearly not the case for postpartum acyclicity which can occur in ewes lambing during the mating season. Although the 2 acyclic states occur for different reasons, some aspects of the aetiology could be similar and a comparison could help to elucidate the mechanisms underlying post-partum acyclicity.

The comparison of post-partum ewes with steroid-treated, ovariectomized ewes (Crowder $e t$ al., 1981,1982 ) may not have been appropriate. We have previously studied post-partum acyclic ewes after they had lambed in the mating season (Wright et al., 1980, 1981). In the present study we have compared plasma and pituitary LH, FSH and prolactin concentrations, hypothalamic Gn-RH and hypothalamic and pituitary oestrogen receptors in post-partum and seasonally anoestrous ewes.

\section{Materials and Methods}

Sheep. The experiment was performed in early December using 2 groups of Corriedale ewes of the same strain so that one group $(\mathrm{N}=8)$ was in seasonal anoestrus, which extends from September to February for this breed at this location. The other group of ewes $(N=9)$ which lambed between 1 and 6 December was studied soon after parturition and each was suckling 1 lamb; the interval from lambing to experimentation is given below. Inspection of the ovaries at the time of killing revealed no fresh ovulations.

Hormones and reagents. Synthetic $\mathrm{Gn}-\mathrm{RH}$ for iodination and assay standards was purchased from Peninsula Labs, Palo Alto, CA, U.S.A. Tritiated oestradiol (sp. act. 4.07 TBq/mmol) was purchased from New England Nuclear, Boston, MA, U.S.A., and purified by chromatography on a $10 \times 0.5 \mathrm{~cm}$ Sephadex LH-20 column developed in chloroform : benzene : methanol $(30: 60: 10$ by vol.). Diethylstilboestrol was obtained from Steraloids, Wilton, NH, U.S.A. All laboratory chemicals were Analar grade.

Experimental procedure. The concentrations of LH, FSH and prolactin were measured in plasma of post-partum (8-14 days after lambing) and seasonally anoestrous ewes by taking jugular venous blood samples at 20-min intervals for a 6-h period beginning at $09: 00 \mathrm{~h}$. The animals were held in individual pens and samples were taken via indwelling jugular venous catheters kept patent with heparinized $(75 \mathrm{U} / \mathrm{ml})$ saline $(0 \cdot 15 \mathrm{M}-\mathrm{NaCl})$. The plasma was stored at $-20^{\circ} \mathrm{C}$ until assay.

At 3 days after blood sampling, 7 of the seasonally anoestrous and 8 post-partum ewes were killed for the collection of tissues. The post-partum ewes were killed 11-17 days after lambing and had all been suckling until this time. The hypothalami and pituitary glands were removed as previously described (Clarke, Burman, Funder \& Findlay, 1981). The pituitary stalk-median eminence was dissected free of other tissues and snap-frozen by plunging into $1 \mathrm{ml}$ acidified $(0.01 \mathrm{M}$ acetic acid) methanol at $-20^{\circ} \mathrm{C}$; these samples were homogenized and stored at $-20^{\circ} \mathrm{C}$ for $\mathrm{Gn}-\mathrm{RH}$ assay. The pituitary glands were bisected by a midline sagittal cut and half of each gland was frozen for subsequent LH, FSH and prolactin assay. The other half of each gland was homogenized in $10 \mathrm{~mm}$-Tris- $\mathrm{HCl}$ containing $1.5 \mathrm{~mm}$-EDTA and $1 \mathrm{~mm}$-dithiothreitol buffer. This was used immediately for receptor analysis (see below). The hypothalamus was dissected as previously described (Clarke et al., 1981), homogenized in buffer and used immediately for receptor analysis (see below). The collections of neuroendocrine tissues were made within 5 min of death.

Oestrogen receptor analysis. Oestrogen receptor content of hypothalami and hemi-pituitary glands was measured by saturation analysis using the methodology validated by Clarke et al. $(1981)$ 
for ovine neuroendocrine tissues. Cytosolic receptors were measured in high speed $(105000 \mathrm{~g})$ supernatants by overnight incubation of $200 \mu \mathrm{l}$ cytosol in the presence of $6 \mathrm{nM}-\left[{ }^{3} \mathrm{H}\right]$ oestradiol- $17 \beta+$ $0.6 \mathrm{~mm}$-diethylstilboestrol at $4^{\circ} \mathrm{C}$. An exchange assay (Clarke et al., 1981) was used to measure the number of receptors translocated to the nuclear compartment in the pituitary gland. Nuclear uptake of oestrogen receptors was not measured in hypothalamic tissues.

Receptor content was expressed per gram wet weight which allowed an estimation of the proportion of the total receptor content that had been translocated to the nuclear compartment.

Radioimmunoassays. The amount of $\mathrm{Gn}-\mathrm{RH}$ in median eminence tissues was measured by radioimmunoassay using the R42 antiserum described by Nett, Akbar, Niswender, Hedlund \& White (1973). The methanolic homogenates were centrifuged for $30 \mathrm{~min}$ at $1500 \mathrm{~g}$ and $4^{\circ} \mathrm{C}$. The supernatants were removed and dried under nitrogen and the residues reconstituted in $1 \mathrm{ml}$ assay buffer. Appropriate dilutions of the extracts were made so that unknown samples were read on the portion of the standard curve where the within-assay coefficient of variation (c.v.) was $<10 \%$. Tracer was prepared by the chloramine T method (Nett et al., 1973) and the mono-iodinated GnRH was obtained by elution through QAE Sephadex (Nett \& Adams, 1977). The assay was performed in plastic tubes as described by Jonas, Burger, Cumming, Findlay \& de Kretser (1975). Precipitates were counted in a Packard auto-gamma scintillation spectrometer Model 5130 and assay results were calculated using the computer program of Burger, Lee \& Rennie (1972). The assay had a sensitivity of $0.2 \mathrm{pg} /$ tube. All samples were measured in a single assay.

Hemi-pituitaries collected to measure hormone content were thawed and homogenized in $10 \mathrm{ml}$ $0.1 \mathrm{M}-\left(\mathrm{NH}_{4}\right)_{2} \mathrm{SO}_{4}$, put into a shaker bath in iced water for $2 \mathrm{~h}$ and then centrifuged at $17000 \mathrm{~g}$ and $4^{\circ} \mathrm{C}$ for $30 \mathrm{~min}$ (Foster et al., 1972). The supernatant was taken for LH and FSH assay. The precipitate containing prolactin was taken up in $10 \mathrm{ml}$ ethanol : sodium hydroxide $(3: 1 \mathrm{v} / \mathrm{v})(\mathrm{J}$ iang \& Wilhelmi, 1965). Pituitary extracts were assayed at 3 dilutions to check that the samples ran parallel to the standard curve.

The LH, FSH and prolactin assays have been described previously by Lee et al. (1976), Bremner, Findlay, Lee, de Kretser \& Cumming (1980) and Clarke, Funder \& Findlay (1982), respectively, using NIH-oLH-S18, NIH-oFSH-S6 and NIH-oPRL-S8 as standards. The assay results were computed by the method of Burger et al. (1972). Samples were read from the portion of the standard curve where the intra-assay c.v. was $<20 \%$. At maximum precision intra-assay c.v. was $4 \cdot 3-4 \cdot 9 \%$ for LH (4 assays), $4 \cdot 5-5 \cdot 0 \%$ for FSH (4 assays) and $4 \cdot 5-5 \cdot 2 \%$ for prolactin (4 assays). Assay sensitivities were $0.2-0.3 \mathrm{ng} \mathrm{LH} / \mathrm{ml}, 12-21 \mathrm{ng} \mathrm{FSH} / \mathrm{ml}$ and $0.9-1 \cdot 1 \mathrm{ng}$ prolactin $/ \mathrm{ml}$. The between-assay c.v. was $7 \%$ at $14.7 \pm 1 \cdot 1$ (s.d.) $\mathrm{ng} / \mathrm{ml}$ and $9 \%$ at $24.2 \pm 2.3 \mathrm{ng} / \mathrm{ml}$ for $\mathrm{LH}, 8 \%$ at $72 \pm$ $6 \mathrm{ng} / \mathrm{ml}$ and $11 \%$ at $196 \pm 22 \mathrm{ng} / \mathrm{ml}$ for $\mathrm{FSH}$, and $17 \%$ at $10 \cdot 3 \pm 1.8 \mathrm{ng} / \mathrm{ml}$ and $7 \%$ at $66.3 \pm 4 \cdot 8$ $\mathrm{ng} / \mathrm{ml}$ for prolactin.

Analysis of data. Plasma $\mathrm{LH}$ values were analysed in terms of mean values and the number of pulsatile secretory episodes ('pulses') during the sampling period. A 'pulse' was defined as having occurred if the assay value of a particular sample exceeded the assay value of the previous sample by more than 3 times the standard deviation (s.d.) of the assay value of the previous sample (s.d. given by the computation of the assay). For FSH and prolactin, animal mean values were calculated and used for between-group comparisons. For prolactin, the values obtained during the first hour of sampling were not included in the analysis because these may have been influenced by stress, known to occur at the start of such procedures (Lamming, Moseley \& McNeilly, 1974). Student's $t$ test was used for statistical comparisons.

\section{Results}

\section{Plasma hormone concentrations}

$L H$. During the 6-h sampling period transitory elevations in plasma $\mathrm{LH}$ levels reflecting pulsatile secretory episodes occurred in $8 / 9$ post-partum ewes and $2 / 8$ seasonally anoestrous ewes 
(a)
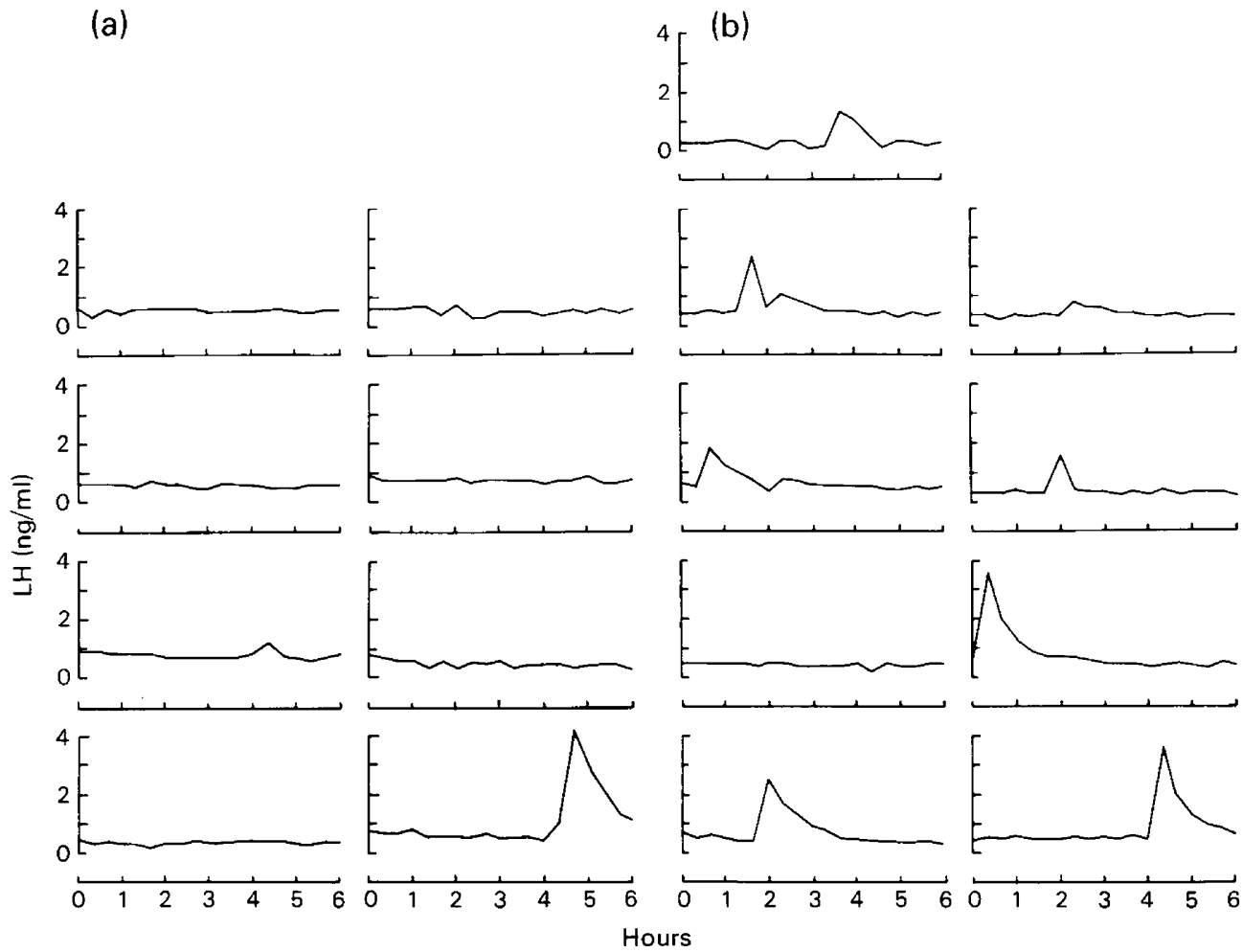

Text-fig. 1. Plasma LH concentrations in ewes during (a) seasonal anoestrus or (b) within 7-14 days of lambing.

$\left(\chi^{2}=4.994, P<0.05\right)$ (Text-fig. 1$)$. Mean $( \pm$ s.e.m.) pulse amplitude was $1.8 \pm 0.3 \mathrm{ng} / \mathrm{ml}$ in postpartum ewes and 3.1 and $0.4 \mathrm{ng} / \mathrm{ml}$ in the 2 seasonally anoestrous ewes. The small number of pulses in seasonally anoestrous ewes prevented further analysis of these data.

$F S H$. Mean ( \pm s.e.m.) plasma concentrations of FSH were $64 \pm 13 \mathrm{ng} / \mathrm{ml}$ in post-partum ewes and $76 \pm 11 \mathrm{ng} / \mathrm{ml}$ in seasonally anoestrous ewes $(P>0.05)$.

Prolactin. Mean ( \pm s.e.m.) plasma concentrations of prolactin were $858 \pm 338 \mathrm{ng} / \mathrm{ml}$ in postpartum ewes and $355 \pm 65 \mathrm{ng} / \mathrm{ml}$ in seasonally anoestrous ewes $(P<0.05)$.

\section{Pituitary hormone contents}

There were no significant differences between the 2 groups in the amounts of LH, FSH and prolactin in pituitaries (Table 1).

\section{Gn-RH content of the median eminence}

Mean ( \pm s.e.m.) levels of $\mathrm{Gn}-\mathrm{RH}$ in the median eminence were $2.34 \pm 0.43$ and $3.06 \pm 0.55$ $\mathrm{ng} / \mathrm{mg}$ wet weight for post-partum and seasonally anoestrous ewes respectively $(P>0.05)$.

\section{Oestrogen receptors}

Nuclear-bound oestrogen receptor values were less $(P<0.01)$ in the post-partum ewe pituitaries than in the seasonally anoestrous ewe pituitaries (Table 1). Cytosolic oestrogen receptor contents were similar in the pituitaries and hypothalami of the two groups. 
Table 1. Content (mean \pm s.e.m.) of LH, FSH and prolactin in the pituitary and oestrogen receptors in pituitary and hypothalamus of postpartum and seasonally anoestrous ewes

\begin{tabular}{|c|c|c|}
\hline & $\begin{array}{l}\text { Post-partum } \\
\text { ewes }\end{array}$ & $\begin{array}{c}\text { Seasonally anoestrous } \\
\text { ewes }\end{array}$ \\
\hline No. & 9 & 8 \\
\hline \multicolumn{3}{|c|}{ Pituitary hormone content } \\
\hline LH $(\mu \mathrm{g} / \mathrm{g})$ & $345 \pm 65$ & $538 \pm 112$ \\
\hline FSH $(\mu \mathrm{g} / \mathrm{g})$ & $1453 \pm 193$ & $1704 \pm 262$ \\
\hline Prolactin $(\mathrm{mg} / \mathrm{g})$ & $28.7 \pm 9.9$ & $20.9 \pm 8.5$ \\
\hline \multicolumn{3}{|c|}{$\begin{array}{l}\text { Oestrogen receptor content } \\
\text { (fmol/g wet wt) }\end{array}$} \\
\hline \multicolumn{3}{|c|}{ Pituitary } \\
\hline Cytosolic & $4138 \pm 225$ & $4704 \pm 475$ \\
\hline Nuclear & $145 \pm 17^{*}$ & $387 \pm 37$ \\
\hline \multicolumn{3}{|l|}{ Hypothalamus } \\
\hline Cytosolic & $117 \pm 9$ & $135 \pm 27$ \\
\hline Nuclear & 二 & 二 \\
\hline
\end{tabular}

\section{Discussion}

In the post-partum acyclic ewe the frequency of pulsatile discharges of LH is greater than that in the seasonally anoestrous ewe. This is consistent with previous studies in which ewes that lambed during the mating season had higher LH pulse frequencies than did dioestrous ewes (Wright et al., 1981). It is generally accepted that the LH pulse frequency during seasonal anoestrus is less than at any time during the oestrous cycle (Yuthasastrakosol, Palmer \& Howland, 1975; Scaramuzzi \& Baird, 1977) which may be a contributory cause of acyclicity (Karsch, 1980). We have previously suggested that post-partum acyclicity in ewes lambing during the mating season is also due to an inability to generate LH pulses of sufficient frequency to cause ovulation (Wright et al., 1983a; Wright, Clarke \& Findlay, 1983b). The present results are consistent with this but demonstrate a fundamental difference in LH pulse frequency between the two acyclic groups. Pregnancy appears to interfere with the circannual pattern of reproductive activity in such a way that LH secretory patterns during the post-partum interval are more pronounced than in anoestrous controls at the same time of the year. The reason for this is unknown. Whereas seasonal acyclicity results from a neuroendocrine disposition that has a photoperiodic aetiology, post-partum acyclicity could be the result of a variety of other factors. Uterine involution and ovarian 'insensitivity' to gonadotrophins (see below) are factors which may contribute to acyclicity post partum but their importance has not yet been evaluated.

Stores of $\mathrm{Gn}-\mathrm{RH}$ in the stalk/median eminence of post-partum ewes are similar in quantity to those in seasonally anoestrous ewes. The amount of Gn-RH in the median eminence region is probably a reliable indicator of Gn- $\mathrm{RH}$ available for release into the hypothalamo-pituitary portal blood since this is where most of the Gn-RH is stored (Polkowska, Dubois \& Domanski, 1980). It has been reported that Gn-RH activity in the median eminence of seasonally anoestrous ewes is equal to or greater than the activity in cyclic ewes (Jackson, Roche, Foster \& Dziuk, 1971), and similar to that between Days 3 and 8 of the oestrous cycle (Wheaton, 1979).

Pituitary LH levels in seasonally anoestrous ewes are also similar to those between Days 3 and 8 of the oestrous cycle (Wheaton, 1979). Before the ovulatory LH surge, during pro-oestrus, there is an increase in Gn-RH levels in the median eminence, and this is accompanied by an increase in pituitary LH content (Roche, Foster, Karsch, Cook \& Dziuk, 1970; Crighton, Hartley \& Lamming, 1973; Wheaton, 1979). It seems reasonable to presume that cyclic variations of Gn-RH and LH do not occur in seasonally anoestrous or post-partum acyclic ewes during the anoestrous season and that the lack of cyclic variation represents a neuroendocrine block at hypothalamic or higher neural 
centres. During pregnancy pituitary LH stores drop to levels much lower than found during anoestrus (Chamley, Jonas \& Parr, 1976). The present results show that LH stores are rapidly replenished within 2 weeks of parturition, in our Corriedale ewes, confirming earlier studies (Jenkins et al., 1977; Wright et al., 1980; Crowder et al., 1982) in other breeds of sheep.

Cytosolic oestrogen receptor concentrations in the hypothalamus and pituitary were similar in post-partum and anoestrous ewes, suggesting that post-partum acyclicity is not due to an alteration at this level. More receptors were present in the nuclear compartment of pituitary glands from anoestrous ewes than in glands from post-partum ewes. Such a difference may reflect higher circulating oestrogen levels in the former (Clarke et al., 1981). This suggests that the follicles in the ovaries of the post-partum ewes were relatively less active than those in anoestrous ewes, in spite of the fact that LH secretion was greater in the former. Further work is needed to appraise fully the status of ovarian follicles during the post-partum period.

Findlay \& Cumming (1976) have previously reported that plasma FSH concentrations in lactating ewes ( 3 months after lambing) were similar to those in non-lactating anoestrous ewes. The present results show that basal FSH concentrations are restored within 2 weeks post partum and are consistent with the findings of Crowder et al. (1982) on Gn-RH-stimulated FSH release. It appears that FSH is not a limiting factor for follicular development in the post-partum ewe.

Prolactin secretion in post-partum anoestrous ewes was greater than that in seasonally anoestrous ewes, as found by others (Lamming et al., 1974; Kann \& Denamur, 1974). Pituitary prolactin content was similar in both groups, indicating that the greater secretion post partum is due to greater synthesis of prolactin.

Appropriate Gn-RH stimulation can cause ovulation in post-partum and seasonally anoestrous ewes (McLeod, Haresign \& Lamming, 1982; Wright et al., 1983a, b), suggesting a neuroendocrine basis for the block in cyclicity. Hyperprolactinaemia may be a cause of the failure to exhibit $\mathrm{LH}$ positive feedback to oestrogen within 14 days post partum because reduction of plasma prolactin concentrations with bromocriptine can restore oestrogen responsiveness (Kann, Martinet \& Schirar, 1978). In such experiments it is difficult to dismiss the possibility that bromocriptine has a direct effect on LH releasing mechanisms. Thus, hyperprolactinaemia may be partly responsible for post-partum acyclicity in ewes but the mechanism for this is unclear.

Although a neuroendocrine lesion is involved, the present study shows that stores and secretions of Gn-RH, LH and FSH are probably not limiting factors post partum. Ovarian follicular development (measured indirectly by translocation of oestrogen receptors) may be diminished. Pregnancy appears, at least in part, to negate the effects of season on LH secretion.

We thank Mr B. Doughton, Mr T. Gill, Ms F. Dench and Mrs Ann Bartlett for technical assistance; and Professor L. E. Reichert Jr and the NIH for purified pituitary hormones for RIA. This work was supported by a grant from the Australian Meat Research Council.

\section{References}

Baird, D.T., McNeilly, A.S., Sawers, R.S. \& Sharpe, R.M. (1979) Failure of oestrogen induced discharge of luteinizing hormone in lactating women. J. clin. Endocr. Metab. 49, 500-506.

Bremner, W.J., Findlay, J.K., Lee, V.W.K., de Kretser, D.M. \& Cumming, I.A. (1980) Feedback effects of the testis on pituitary responsiveness to luteinizing hormone-releasing hormone infusions in the ram. Endocrinology 106, 329-336.

Burger, H.G., Lee, V.W.K. \& Rennie, G.C. (1972) A generalized computer program for the treatment of data from competitive protein-binding assays including radioimmunoassays. J. Lab. clin. Med. 80, 302-312.
Chamley, W.A., Findlay, J.K., Cumming, I.A., Buckmaster, J.M. \& Goding, J.R. (1974) Effect of pregnancy on the $\mathrm{LH}$ response to synthetic gonadotropinreleasing hormone in the ewe. Endocrinology 94, 291293.

Chamley, W.A., Jonas, H.A. \& Parr, R.A. (1976) Content of LH, FSH and growth hormone in the pituitaries of pregnant and anestrous sheep. Endocrinology 98, 1535-1538.

Clarke, I.J., Burman, K., Funder, J.W. \& Findlay, J.K. (1981) Estrogen receptors in the neuroendocrine tissues of the ewe in relation to breed, season and stage of the estrous cycle. Biol. Reprod. 24, 323331 . 
Clarke, I.J., Funder, J.W. \& Findlay, J.K. (1982) Relationship between pituitary nuclear oestrogen receptors and the release of $\mathrm{LH}, \mathrm{FSH}$ and prolactin in the ewe. J. Reprod. Fert. 64, 355-362.

Crighton, D.B., Hartley, B.M. \& Lamming, G.E. (1973) Changes in the luteinizing hormone releasing activity of the hypothalamus, and in pituitary gland and plasma luteinizing hormone during the oestrous cycle of the sheep. J. Endocr. 58, 377-385.

Crowder, M.E., Gilles, P.A. \& Tamanini, C. (1981) Changes in hypophyseal receptors for Gn-RH and estradiol in steroid treated and post partum ewes. Biol. Reprod. 24, Suppl. 1, Abstr. 121.

Crowder, M.E., Gilles, P.A., Tamanini, C., Moss, C.E. \& Nett, T.M. (1982) Pituitary content of gonadotropins and Gn-RH-receptors in pregnant, postpartum and steroid treated ovariectomized ewes. J. Anim. Sci. 54, 1235-1242.

Elsaesser, F. \& Parvizi, N. (1980) Partial recovery of the stimulatory oestrogen feedback action on LH release during late lactation in the pig. J. Reprod. Fert. 59, 63-67.

Findlay, J.K. \& Cumming, I.A. (1976) FSH in the ewe: effects of season, liveweight and plane of nutrition on plasma FSH and ovulation rate. Biol. Reprod. 15, 335-342.

Foster, D.L., Roach, J.F., Karsch, F.J., Norton, H.W., Cook, B. \& Nalbandov, A.V. (1972) Regulation of luteinizing hormone in the fetal and neonatal lamb. 1. LH concentrations in blood and pituitary. Endocrinology 90, 102-111.

Jackson, G.L., Roche, J.F., Foster, D.L. \& Dziuk, P.J. (1971) Luteinizing hormone releasing activity in the hypothalamus of anestrous and cyclic ewes. Biol. Reprod. 5, 5-12.

Jenkin, G., Heap, R.B. \& Symons, D.B.A. (1977) Pituitary responsiveness to synthetic LH-RH and pituitary $\mathrm{LH}$ content at various reproductive stages in the sheep. J. Reprod. Fert. 49, 207-214.

Jiang, N.-S. \& Wilhelmi, A.E. (1965) Preparation of bovine, ovine and porcine prolactin. Endocrinology 77, 150-154.

Jonas, H.A., Burger, H.G., Cumming, I.A., Findlay, J.K. \& de Krester, D.M. (1975) Radioimmunoassay for luteinizing hormone-releasing hormone (LHRH): its application to the measurement of LHRH in ovine and human plasma. Endocrinology 96, 384-393.

Kann, G. \& Denamur, R. (1974) Possible role of prolactin during the oestrous cycle and gestation in the ewe. $J$. Reprod. Fert. 39, 473-483.

Kann, G., Martinet, J. \& Schirar, A. (1978) Hypothalamic-pituitary control during lactation in sheep. In Control of Ovulation, pp. 319-333. Eds D. B. Crighton, G. R. Foxcroft, N. B. Haynes \& G. E. Lamming. Butterworths, London.

Karsch, F.J. (1980) Seasonal reproduction: a saga of reversible fertility. The Physiologist 23, 29-38.

Lamming, G.E., Moseley, S.R. \& McNeilly, J.R. (1974) Prolactin release in the sheep. J. Reprod. Fert. 40, 151-168.

Lee, V.W.K., Cumming, I.A., de Kretser, D.M., Findlay, J.K., Hudson, B. \& Keogh, E.J. (1976) Regulation of gonadotrophin secretion in rams from birth to sexual maturity. I. Plasma LH, FSH and testosterone levels. J. Reprod. Fert. 46, 1-6.

Legan, S.L., Karsch, F.J. \& Foster, D.L. (1977) The endo- crine control of seasonal reproductive function in the ewe: a marked change in response to the negative feedback action of estradiol in luteinizing hormone secretion. Endocrinology 101, 818-824.

Mcleod, B.J., Haresign, W. \& Lamming, G.E. (1982) The induction of ovulation and luteal function in seasonally anoestrous ewes treated with small-dose multiple injections of Gn-RH. J. Reprod. Fert. 65, 215-221.

Nett, T.M. \& Adams, T.E. (1977) Further studies on the radioimmunoassay of gonadotropin releasing hormone: effect of radioiodination, antiserum and unextracted serum on levels of immunoreactivity in serum. Endocrinology 101, 1135-1144.

Nett, T.M., Akbar, A.M., Niswender, G.D., Hedlund, M.T. \& White, W.F. (1973) A radioimmunoassay for gonadotropin-releasing hormone (Gn-RH) in serum. J. clin. Endocr. Metab. 36, 880-885.

Polkowska, J., Dubois, M.P. \& Domanski, E. (1980) Immunocytochemistry of luteinizing hormone releasing hormone (LH-RH) in the sheep hypothalamus during various reproductive stages. Correlation with the gonadotropic hormones of the pituitary. Cell Tiss. Res. 208, 327-341.

Radford, H.M., Nancarrow, C.D. \& Mattner, P.E. (1978) Ovarian function in suckling and non-suckling beef cows post partum. J. Reprod. Fert. 54, 49-56.

Roche, J.F., Foster, D.L., Karsch, F.J., Cook, B. \& Dziuk, P.J. (1970) Levels of luteinizing hormone in sera and pituitaries of ewes during the estrous cycle and anestrus. Endocrinology 86, 568-572.

Scaramuzzi, R.J. \& Baird, D.T. (1977) Pulsatile release of luteinizing hormone and the secretion of ovarian steroids in sheep during anestrus. Endocrinology 101, 1801-1806.

Wheaton, J.E. (1979) Regional brain content of luteinizing hormone-releasing hormone in sheep during the estrous cycle, seasonal anestrus, and after ovariectomy. Endocrinology 104, 839-844.

Wright, P.J., Geytenbeek, P.E., Clarke, I.J. \& Findlay, J.K. (1980) Pituitary responsiveness to LH-RH, the occurrence of oestradiol-17 $\beta$-induced LH-positive feedback and the resumption of oestrous cycles in ewes post partum. J. Reprod. Fert. 60, 171-176.

Wright, P.J., Geytenbeek, P.E., Clarke, I.J. \& Findlay, J.K. (1981) Evidence for a change in oestradiol negative feedback and LH pulse frequency in postpartum ewes. J. Reprod. Fert. 61, 97-102.

Wright, P.J., Geytenbeek, P.E., Clarke, I.J. \& Findlay, J.K. (1983a) LH release and luteal function in postpartum acyclic ewes after the pulsatile administration of LH-RH. J. Reprod. Fert. 67, 257-262.

Wright, P.J., Clarke, I.J. \& Findlay, J.K. (1983b) The induction of fertile oestrus in seasonally anoestrous ewes using a continuous low dose administration of gonadotrophin releasing hormone. Aust. vet. J. 60, 254-255.

Yamaji, T., Dierschke, D.J., Hotchkiss, J., Bhattacharya, A.N., Surve, A.H. \& Knobil, E. (1971) Estrogen induction of LH release in the Rhesus monkey. Endocrinology 89, 1034-1041.

Yuthasastrakosol, P., Palmer, W.M. \& Howland, B.E. (1975) Luteinizing hormone, oestrogen and progesterone levels in peripheral serum of anoestrous and cyclic ewes as determined by radioimmunoassay. J. Reprod. Fert. 43, 57-65. 